\title{
Evaluation of software tools supporting outcomes-based continuous program improvement processes
}

\author{
James Kaupp ${ }^{1}$, Brian Frank ${ }^{1}$ and Christopher Watts $^{2}$ \\ ${ }^{1}$ Queen's University, ${ }^{2}$ Dalhousie University \\ kaupp@appsci.queensu.ca
}

\begin{abstract}
The Canadian engineering accreditation board (CEAB) mandate tasked each engineering program to assess student outcomes in the form of graduate attributes and develop a data-informed continuous program improvement stemming from those assessments.

Administering, collecting and organizing the breadth assessment data is an extensive process, typically centralized through the use of software tools such as learning management systems (LMS), content management systems (CMS), continuous program improvement systems (CPI). These systems serve a variety of roles, ranging from course content delivery, $e$ learning, distance education, learning outcomes assessment, outcomes data management and learning outcomes analytics. Vendors have been developing various solutions to accommodate the shift towards outcomes based assessment as part of a continuous improvement processes.

This paper will compare and contrast software tools supporting outcomes based assessment as part of a continuous improvement process such as eLumen, Canvas, Moodle, WaypointOutcomes, Desire2Learn and LiveText.
\end{abstract}

Keywords: Learning outcomes analytics, Outcomes based assessment, Learning management software, Continuous improvement processes, change management processes

\section{INTRODUCTION}

As Canadian engineering programs proceed with meeting the Canadian Engineering Accreditation Boards mandate of developing an outcomes-based, data-informed continuous improvement process, there have been many questions regarding hallmarks of effective processes.

There is considerable research on how best to create and assess student learning outcomes[1]-[3]. However, there is less literature addressing using learning outcomes as part of CPI process despite considerable need for the investigation into best practices. The reports from the Wabash National Study[4]-[6] have provided a strong foundation and beginnings of best practices, but questions still remain. One of the foremost questions deals with the use of educational software tools to assist in the change management process of the CEAB accreditation mandate. Institutions must evaluate how these software tools can assist a sustainable outcomes based CPI process through the support of the collection, assessment, management and analysis of learning outcomes data. This is a challenging endeavor, as considerable resources must be invested to the successful, sustainable, long-term adoption of a software tool[7]. If the software tool is adopted without sufficient support, internal championing or consideration to change management issues, then it is unlikely to develop into a sustainable, long-term practice[5], [6].

The current landscape of software tools for outcomes based CPI processes is diverse. There are many vendors that offer a multitude of products catering to a variety of needs. These solutions range from learning and/or content management systems, specialized assessment tools, continuous program improvement solutions and integrative solutions that seek to supplement existing processes for outcomes assessment and reporting. The primary challenge is that little information exists which compares and contrasts the features and relative strengths of each solution.

It is the purpose of this paper to present, compare and evaluate a variety of commercially and freely available software tools that support outcomes based assessment as part of a CPI process. To that end, six software tools were evaluated: eLumen, Canvas, Moodle, WaypointOutcomes, Desire2Learn, and LiveText.

\section{EVALUATION METHOD}

The vendors for each software tool were contacted and asked to deliver a presentation regarding the strengths and contributions of their particular software tool. Presentations were directed towards outcomes based assessment, data management, outcomes analytics and continuous program improvement capabilities. Wherever possible, a live demo or sandbox environment was requested to evaluate the system. 
Following the presentations, the software tools were classified by 3 independent criteria and evaluated by 4 independent criteria, illustrated below.

\subsection{System Classification}

The evaluation element classifies the software tool by the following criteria:

Table 1: System Classification

\begin{tabular}{|l|l|}
\hline Category & Description \\
\hline LMS & $\begin{array}{l}\text { Learning management system. Capable of delivering } \\
\text { content and administration for course offerings. May offer } \\
\text { integrated learning outcomes assessment and analytics. }\end{array}$ \\
\hline L/CMS & $\begin{array}{l}\text { Learning content management system. Capable of creating } \\
\text { and delivering content and managing grades for a multitude } \\
\text { of courses. In addition can offer e-learning and distance } \\
\text { based courses, supports collaborative content, publishing } \\
\text { elements, e-portfolios and facilitated content management. } \\
\text { May offer integrated learning outcomes assessment and } \\
\text { analytics. }\end{array}$ \\
\hline CPI & $\begin{array}{l}\text { Continuous program improvement tool. Capable of } \\
\text { creating assessment elements to evaluate, analyze and } \\
\text { report student performance in learning outcomes. Focuses } \\
\text { on assessment of select evidence for outcomes. Is not a } \\
\text { platform for content creation or delivery }\end{array}$ \\
\hline
\end{tabular}

\subsection{System Integration}

This evaluation element describes how the software tool is integrated with other educational technology, human resource systems and $3^{\text {rd }}$ party applications:

Table 2: System Integration

\begin{tabular}{|l|l|}
\hline Category & Description \\
\hline \multirow{4}{*}{ LTI } & $\begin{array}{l}\text { Learning Tools Interoperability } \\
\text { (http://www.imsglobal.org/toolsinteroperability2.cfm). A } \\
\text { specification developed by IMS global to allow different } \\
\text { learning tools a way to interface with a variety of } 3^{\text {rd }} \text { party } \\
\text { tools. LTI allows for a secure link to be created from a } \\
\text { learning tool to another } 3^{\text {rd }} \text { party application. }\end{array}$ \\
\hline \multirow{3}{*}{ API } & $\begin{array}{l}\text { Application Programming Interface (API). A standard } \\
\text { protocol intended to be used as an interface allowing } \\
\text { software tools to communicate with other } 3^{\text {rd }} \text { party } \\
\text { applications. }\end{array}$ \\
\hline Custom & $\begin{array}{l}\text { Custom interface or wizard developed to import or export } \\
\text { data into the software or } 3^{\text {rd }} \text { party application }\end{array}$ \\
\hline
\end{tabular}

\subsection{Rubric-based Assessment}

This evaluation element focuses on the software tools use of rubrics in assessment of student submissions. Ease of rubric creation, customization and storage for future use and sharing is considered.

Table 3: Rubric-based Assessment

\begin{tabular}{|c|c|c|c|}
\hline Outcome & 1 star & 2 Stars & 3 Stars \\
\hline $\begin{array}{l}\text { Rubric } \\
\text { Generation }\end{array}$ & $\begin{array}{l}\text { Rubric } \\
\text { generation is } \\
\text { present but } \\
\text { poorly } \\
\text { implemented. } \\
\text { User interface is } \\
\text { obscuring or } \\
\text { confusing, } \\
\text { requiring } \\
\text { comprehensive } \\
\text { training }\end{array}$ & $\begin{array}{l}\text { Rubric } \\
\text { generation is } \\
\text { an } \\
\text { implemented } \\
\text { feature. User } \\
\text { interface } \\
\text { requires } \\
\text { training prior } \\
\text { to use. }\end{array}$ & $\begin{array}{l}\text { Rubric } \\
\text { generation is } \\
\text { excellently } \\
\text { implemented. } \\
\text { Allows for } \\
\text { quick, easy } \\
\text { creation and is } \\
\text { easily accessed. }\end{array}$ \\
\hline Customization & $\begin{array}{l}\text { Rubric outcomes } \\
\text { and assessment } \\
\text { levels can be } \\
\text { customized but } \\
\text { is poorly } \\
\text { implemented, or } \\
\text { customization is } \\
\text { limited by } \\
\text { imposed } \\
\text { restraints. }\end{array}$ & $\begin{array}{l}\text { Rubric } \\
\text { outcomes and } \\
\text { assessment } \\
\text { levels can be } \\
\text { customized } \\
\text { according to } \\
\text { user } \\
\text { preference. } \\
\text { Outcomes } \\
\text { must be } \\
\text { specified for } \\
\text { each rubric } \\
\text { element. }\end{array}$ & $\begin{array}{l}\text { Full } \\
\text { customization } \\
\text { of rubric } \\
\text { outcomes and } \\
\text { assessment } \\
\text { levels is } \\
\text { possible and } \\
\text { easily done. } \\
\text { Outcomes can } \\
\text { be added from } \\
\text { repositories } \\
\text { into rubrics. }\end{array}$ \\
\hline $\begin{array}{l}\text { Rubric } \\
\text { Repository }\end{array}$ & $\begin{array}{l}\text { Created rubrics } \\
\text { are available for } \\
\text { future by a } \\
\text { template } \\
\text { structure. }\end{array}$ & $\begin{array}{l}\text { Created } \\
\text { rubrics are } \\
\text { archived by } \\
\text { specific course } \\
\text { or department } \\
\text { into a } \\
\text { repository. } \\
\text { Users can } \\
\text { search for } \\
\text { rubrics by } \\
\text { specific text. }\end{array}$ & $\begin{array}{l}\text { Created rubrics } \\
\text { can be placed } \\
\text { into a } \\
\text { searchable } \\
\text { repository } \\
\text { available to all } \\
\text { faculty or } \\
\text { department } \\
\text { members. }\end{array}$ \\
\hline
\end{tabular}

\subsection{Learning Outcomes}

This evaluation element focuses on the software tools use of student learning outcomes. It describes how learning outcomes can be created in an institution and if outcomes can be used at multiple levels (institution, faculty, department, course), if outcomes can be mapped across the levels (outcomes curriculum mapping), if outcomes can be linked to multiple assessment instances, and if outcomes can be archived into a searchable repository. 
Table 4: Learning Outcomes

\begin{tabular}{|l|l|l|l|}
\hline Outcome & 1 star & 2 Stars & 3 Stars \\
\hline $\begin{array}{l}\text { Multi-level } \\
\text { capability }\end{array}$ & $\begin{array}{l}\text { Learning } \\
\text { outcomes can } \\
\text { be created and } \\
\text { assessed at } \\
\text { select levels } \\
\text { with limits or } \\
\text { constraints. }\end{array}$ & $\begin{array}{l}\text { Learning } \\
\text { outcomes can } \\
\text { be created and } \\
\text { assessed at } \\
\text { select levels } \\
\text { (course, } \\
\text { department, } \\
\text { program, } \\
\text { institution) }\end{array}$ & $\begin{array}{l}\text { Learning outcomes } \\
\text { can be created and } \\
\text { assessed across all } \\
\text { levels (course, } \\
\text { department, } \\
\text { program, } \\
\text { institution) }\end{array}$ \\
\hline $\begin{array}{l}\text { Multi-level } \\
\text { mapping }\end{array}$ & $\begin{array}{l}\text { Learning } \\
\text { outcomes can } \\
\text { be mapped at } \\
\text { select levels } \\
\text { with limited } \\
\text { reporting } \\
\text { options. }\end{array}$ & $\begin{array}{l}\text { Learning } \\
\text { outcomes can } \\
\text { be mapped to } \\
\text { select levels of } \\
\text { assessment } \\
\text { with graphical } \\
\text { or tabular } \\
\text { reporting } \\
\text { options. }\end{array}$ & $\begin{array}{l}\text { Learning outcomes } \\
\text { camprehensively } \\
\text { mapped to all areas } \\
\text { of assessment } \\
\text { across all levels, } \\
\text { with a variety of } \\
\text { reporting options }\end{array}$ \\
\hline $\begin{array}{l}\text { Multi- } \\
\text { instance } \\
\text { mapping }\end{array}$ & $\begin{array}{l}\text { Learning } \\
\text { outcomes can } \\
\text { be assessed at } \\
\text { select levels } \\
\text { with limits or } \\
\text { constraints. }\end{array}$ & $\begin{array}{l}\text { Learning } \\
\text { outcomes can } \\
\text { be assessed in } \\
\text { multiple } \\
\text { instances } \\
\text { across select } \\
\text { levels. }\end{array}$ & $\begin{array}{l}\text { Learning outcomes } \\
\text { can be assessed in } \\
\text { multiple instances } \\
\text { or assessments } \\
\text { across all levels }\end{array}$ \\
\hline $\begin{array}{l}\text { Outcomes } \\
\text { Repository }\end{array}$ & $\begin{array}{l}\text { Learning } \\
\text { outcomes can } \\
\text { be archived or } \\
\text { viewed at } \\
\text { select levels } \\
\text { with limits or } \\
\text { constraints to } \\
\text { link to existing }\end{array}$ & $\begin{array}{l}\text { Learning } \\
\text { autcomes can } \\
\text { be archived in } \\
\text { a repository } \\
\text { available for } \\
\text { select groups at } \\
\text { specific levels } \\
\text { to incorporate } \\
\text { into } \\
\text { assessments. }\end{array}$ & $\begin{array}{l}\text { Learning outcomes } \\
\text { can be archived in a } \\
\text { searchable } \\
\text { repository available } \\
\text { for all levels to } \\
\text { incorporate into } \\
\text { rubrics and } \\
\text { assessments. }\end{array}$ \\
\hline
\end{tabular}

\subsection{Assessment}

This evaluation element focuses on the systems assessment capabilities. It describes at the types of student evidence used in assessment, the capability of multiple assessors on submitted evidence, the efficiency of grading student submissions, and the ease and quality of the feedback that can be provided to the student.
Table 5: Assessment

\begin{tabular}{|c|c|c|c|}
\hline Outcome & 1 star & 2 Stars & 3 Stars \\
\hline $\begin{array}{l}\text { Direct \& } \\
\text { Indirect } \\
\text { Evidence }\end{array}$ & $\begin{array}{l}\text { Learning } \\
\text { outcomes can } \\
\text { only } \\
\text { incorporate } \\
\text { multiple forms } \\
\text { of evidence } \\
\text { and is thus } \\
\text { very limited }\end{array}$ & $\begin{array}{l}\text { Assessments can } \\
\text { incorporate both } \\
\text { direct and } \\
\text { indirect } \\
\text { evidence of } \\
\text { student learning } \\
\text { with certain } \\
\text { limitations }\end{array}$ & $\begin{array}{l}\text { Assessments can } \\
\text { incorporate } \\
\text { multiple sources } \\
\text { of both direct and } \\
\text { indirect evidence } \\
\text { of student } \\
\text { learning }\end{array}$ \\
\hline $\begin{array}{l}\text { Multiple } \\
\text { Assessors }\end{array}$ & $\begin{array}{l}\text { Assessments } \\
\text { can be graded } \\
\text { only by course } \\
\text { personnel }\end{array}$ & $\begin{array}{l}\text { Assessments can } \\
\text { be graded by } \\
\text { multiple } \\
\text { assessors from a } \\
\text { variety of } \\
\text { assigned roles }\end{array}$ & $\begin{array}{l}\text { Assessments can } \\
\text { be graded by } \\
\text { multiple } \\
\text { assessors as well } \\
\text { as peer-based } \\
\text { assessment }\end{array}$ \\
\hline $\begin{array}{l}\text { In-line } \\
\text { grading }\end{array}$ & $\begin{array}{l}\text { Grading can } \\
\text { only be done } \\
\text { outside the } \\
\text { student } \\
\text { submission via } \\
\text { a grade-book } \\
\text { or rubric } \\
\text { elements }\end{array}$ & $\begin{array}{l}\text { Grading can be } \\
\text { done by within } \\
\text { the student } \\
\text { submission via } \\
\text { selectable grades } \\
\text { for rubric } \\
\text { elements }\end{array}$ & $\begin{array}{l}\text { Grading can be } \\
\text { done quickly in- } \\
\text { line with rubrics, } \\
\text { while viewing } \\
\text { the student } \\
\text { submission }\end{array}$ \\
\hline $\begin{array}{l}\text { In-line } \\
\text { feedback }\end{array}$ & $\begin{array}{l}\text { The student } \\
\text { submission can } \\
\text { only be } \\
\text { commented on } \\
\text { offline via } \\
\text { commenting } \\
\text { text boxes }\end{array}$ & $\begin{array}{l}\text { The student } \\
\text { submission can } \\
\text { be commented } \\
\text { on in-line via a } \\
\text { comment field. } \\
\text { Comments can } \\
\text { be added for } \\
\text { rubric elements } \\
\text { and the overall } \\
\text { assessment }\end{array}$ & $\begin{array}{l}\text { The student } \\
\text { submission can } \\
\text { be 'marked-up' } \\
\text { and commented } \\
\text { on in-line, } \\
\text { providing rich } \\
\text { feedback. } \\
\text { Comments can } \\
\text { be added for } \\
\text { rubric elements } \\
\text { and the overall } \\
\text { assessment. }\end{array}$ \\
\hline
\end{tabular}

\subsection{Analytics}

This evaluation element focuses on the systems outcomes analytic capabilities. It describes at the availability of reporting across institutional levels (down to student level), the flexibility of both tabular and graphical reporting, how on-demand the reporting methods are, the flexibility of longitudinal reporting methods and the ability to create custom groups (demographic or otherwise) for reporting. 
Table 6: Analytics

\begin{tabular}{|c|c|c|c|}
\hline Outcome & 1 star & 2 Stars & 3 Stars \\
\hline $\begin{array}{l}\text { Multi-level } \\
\text { reporting }\end{array}$ & $\begin{array}{l}\text { Reporting on } \\
\text { standard } \\
\text { metrics \& } \\
\text { learning } \\
\text { outcomes are } \\
\text { limited }\end{array}$ & $\begin{array}{l}\text { Reporting on } \\
\text { standard metrics } \\
\& \text { learning } \\
\text { outcomes can } \\
\text { be run at select } \\
\text { levels }\end{array}$ & $\begin{array}{l}\text { Reporting on } \\
\text { standard metrics } \\
\& \text { learning } \\
\text { outcomes can be } \\
\text { run at any level }\end{array}$ \\
\hline $\begin{array}{l}\text { Tabular } \\
\text { reporting }\end{array}$ & $\begin{array}{l}\text { Reporting on } \\
\text { standard } \\
\text { metrics \& } \\
\text { learning } \\
\text { outcomes is } \\
\text { limited to a } \\
\text { pre-defined } \\
\text { table }\end{array}$ & $\begin{array}{l}\text { Reporting on } \\
\text { standard metrics } \\
\text { \& learning } \\
\text { outcomes can } \\
\text { be reported on } \\
\text { in several pre- } \\
\text { defined tabular } \\
\text { formats }\end{array}$ & $\begin{array}{l}\text { Reporting on } \\
\text { standard metrics } \\
\& \text { learning } \\
\text { outcomes can be } \\
\text { reported on in } \\
\text { customizable } \\
\text { tabular formats }\end{array}$ \\
\hline $\begin{array}{l}\text { Graphical } \\
\text { Reporting }\end{array}$ & $\begin{array}{l}\text { Reporting on } \\
\text { standard } \\
\text { metrics \& } \\
\text { learning } \\
\text { outcomes is } \\
\text { limited to a } \\
\text { pre-defined } \\
\text { graph }\end{array}$ & $\begin{array}{l}\text { Reporting on } \\
\text { standard metrics } \\
\text { \& learning } \\
\text { outcomes can } \\
\text { be reported on } \\
\text { in several pre- } \\
\text { defined } \\
\text { graphical } \\
\text { formats }\end{array}$ & $\begin{array}{l}\text { Reporting on } \\
\text { standard metrics } \\
\& \text { learning } \\
\text { outcomes can be } \\
\text { reported on in } \\
\text { customizable } \\
\text { graphical formats }\end{array}$ \\
\hline $\begin{array}{l}\text { On-demand } \\
\text { reporting }\end{array}$ & $\begin{array}{l}\text { Reporting on } \\
\text { standard } \\
\text { metrics \& } \\
\text { learning } \\
\text { outcomes is } \\
\text { limited. }\end{array}$ & $\begin{array}{l}\text { Reporting on } \\
\text { standard metrics } \\
\& \text { learning } \\
\text { outcomes can } \\
\text { be run only at } \\
\text { specific time } \\
\text { points or key } \\
\text { assessments }\end{array}$ & $\begin{array}{l}\text { Reporting on } \\
\text { standard metrics } \\
\text { \& learning } \\
\text { outcomes can } \\
\text { reported on at } \\
\text { any time }\end{array}$ \\
\hline $\begin{array}{l}\text { Longitudinal } \\
\text { reporting }\end{array}$ & $\begin{array}{l}\text { Longitudinal } \\
\text { reporting on } \\
\text { standard } \\
\text { metrics \& } \\
\text { learning } \\
\text { outcomes is } \\
\text { limited }\end{array}$ & $\begin{array}{l}\text { Longitudinal } \\
\text { reporting on } \\
\text { standard metrics } \\
\text { \& learning } \\
\text { outcomes is } \\
\text { available for } \\
\text { select levels, } \\
\text { metrics or } \\
\text { outcomes }\end{array}$ & $\begin{array}{l}\text { Reporting on } \\
\text { standard metrics } \\
\& \text { learning } \\
\text { outcomes can be } \\
\text { reported } \\
\text { longitudinally for } \\
\text { all levels, metrics } \\
\text { and outcomes }\end{array}$ \\
\hline $\begin{array}{l}\text { Custom } \\
\text { group } \\
\text { reporting }\end{array}$ & $\begin{array}{l}\text { Reporting on } \\
\text { customized } \\
\text { groupings is } \\
\text { limited }\end{array}$ & $\begin{array}{l}\text { Pre-defined } \\
\text { groups can be } \\
\text { created for } \\
\text { reporting of } \\
\text { standard metrics } \\
\text { \& learning } \\
\text { outcomes } \\
\text { within a course } \\
\end{array}$ & $\begin{array}{l}\text { Custom groups } \\
\text { can be created } \\
\text { for reporting of } \\
\text { standard metrics } \\
\text { \& learning } \\
\text { outcomes }\end{array}$ \\
\hline
\end{tabular}

\subsection{Pricing}

This evaluation element focuses on the price of the system. It looks at the hosting model of the system, the duration of the subscription or licensing of the system, and the approximate cost of the system typically derived from full-time equivalent numbers.
Table 7: Pricing

\begin{tabular}{|l|l|}
\hline Category & Description \\
\hline $\begin{array}{l}\text { Hosting } \\
\text { model }\end{array}$ & $\begin{array}{l}\text { Is the software tool hosted on site by the } \\
\text { institution (Self) or is "site as a service" (SaaS) } \\
\text { hosting available? }\end{array}$ \\
\hline Subscription & $\begin{array}{l}\text { Is the software tool available by a designated } \\
\text { subscription or licensing model (Yearly } \\
\text { License) or is it freely available (Open-source) }\end{array}$ \\
\hline Cost & $\begin{array}{l}\text { Cost model and fee for the software tool. Most } \\
\text { software packages are available on pricing that } \\
\text { is scaled on full time equivalent (FTE) numbers }\end{array}$ \\
\hline
\end{tabular}

\section{SOFTWARE TOOL SUMMARIES}

In the interest of providing a rich evaluation of each software tool, a brief summary of each is provided below. These summaries focus on the particular strengths and weaknesses of the software tool that may not evident from the evaluation criterion.

\section{1 eLumen}

eLumen (http://elumen.info/) is a tool with a focus on comprehensive assessment, analytics and reporting of learning outcomes. Its primary strengths are the learning outcomes focus as well as analytics and reporting aspects of the program. eLumen allows for easy creation of learning outcomes within programs and courses for any users, and for users to assess these outcomes via usercreated rubrics. Both outcomes and rubrics can be archived and used by any other user. The reporting and analytics can be run on-demand and exists on a unique database where outcomes reporting drill down to student level, specific outcome, or unique user-defined group.

The weaknesses of eLumen are the lack of integration with other LMS vendors, assessment and feedback. Regarding integration, users have to manually import assessment data through a wizard into the system in order to populate the database. The development of an LTI or API would improve this. In-line assessment is also a weakness of the system, where users cannot view the student evidence within eLumen during assessment and have to have a separate system or physically review the evidence for assessment. Rich assessment feedback is not a capability of the system, with only rubric outcomes scores being provided to students for feedback.

\subsection{Canvas}

Canvas (http://www.instructure.com/) is a unique, web-based open-source LMS with a focus on developing unique content through an open-source API and a large number of $3^{\text {rd }}$ party tools through LTI integration. Canvases primary strengths are learning outcomes, rubrics and assessment. Canvas allows for quick and easy 
creation of learning outcomes to be assessed and shared at any level of an organization with complete customization possible. Rubrics are quickly and easily created with users able to create custom outcomes or search an institution wide database of pre-defined outcomes (related to accreditation or provincial standard). Grading can be done quickly and easily within the student evidence, either by using the rubric or manually assigning a grade. Feedback is a particular strength of Canvas, with graders able to view, mark-up, grade and comment directly on student submitted evidence within a single window.

The weaknesses of the system are the analytics and reporting of student outcomes. All reports are generated from within the system, and have little availability for customization. Reporting is limited to organization groups and only through tabular views, CSV exports, and basic course-level statistics (not outcomes linked). Outcomes reporting access is limited to administrator access, not the course instructor, and only offers basic data aggregation and statistics. Custom reporting, graphical options and custom grouping are not a current feature of Canvas, which limits its outcomes analytics and reporting abilities.

\subsection{Moodle}

Moodle (https://moodle.org/) is an entirely opensource, free to use and customize learning and content management system. Users of Moodle are free to develop their own modules for the program, or install any community-developed application. Moodle's main strength is the open-source nature of the program, which allows for complete customization. This allows users of Moodle to do nearly anything, deliver course content, manage grades, develop rubrics, and assess outcomes. However, while these modules allow for a multitude of uses, the overall integration may not be user friendly and takes considerable effort into developing a professional well-designed course. Modules exist for outcomes based assessment and the creation of evaluation rubrics. These modules allow for outcomes and rubrics to be created, link outcomes to rubrics and create a repository for both, however the interface by which this is accomplished is confusing.

Efficient grading, assessment of outcomes, rich feedback, outcomes analytics and reporting are weakness of the system. Grading has to be done offline then recorded via upload or the grade book, with outcomes being assessed in a similar fashion. Rich feedback is also limited to offline delivery, with graders having to download the student submission, mark-up or comment separately, then re-upload to Moodle in order for the student to read feedback. Outcomes analytics and reporting is a completely manual process, having to download outcomes results from Moodle via a data export, which is often only available at select times during a semester. Reporting must be done in a separate environment or application, such as Excel, in order to construct viewable reports and manage data.

\subsection{Waypoint Outcomes}

Waypoint

Outcomes

(http://www.waypointoutcomes.com/) is an outcomes assessment and reporting tool based around student engagement, authentic assessment, and efficient use of faculty time when grading. This is primarily a CPI tool and is not a standalone LMS, and relies on LTI and API integration to LMS systems. This link allows for assessment of key pieces of student evidence for learning outcomes and the ability to provide rich and detailed feedback in an efficient manner.

Waypoint outcomes strengths are in rubrics, learning outcomes, and assessment. Rubrics are fully customizable and created by instructors within Waypoint Outcomes and can be stored within a searchable repository for others to view and use. Learning outcomes can be created at any level within an institution and are stored within a fully searchable database to integrate into other courses or rubrics. Assessment in Waypoint is a key feature, with grading of student evidence, mark-up of evidence and feedback occurring directly within the system and those results being transferred back to the LMS.

The weaknesses of the system are its outcomes analytics and reporting, which is in the initial stages of development. Some measures of outcomes reporting are available at key assessment points, but the reports are 'canned' and possess minimal measures of customization or graphical options. The 2-stage nature of the tool may also be a drawback to some programs that seek to have a more efficient, singular process. Currently, Waypoint integration is only available with Blackboard Learn, Moodle and Pearson eCollege.

\subsection{Desire2Learn}

Desire2Learn (D2L) (http://www.desire2learn.com/) is a learning content management system with an additional tool package for continuous program improvement support. It provides a learning environment, content management and delivery, assessment tools alongside additional software for learning repositories, student success, outcomes analytics and reporting. D2L supports many third party applications via both API and LTI integration. The strength of Desire2Learn is that is a well-rounded, single system, comprehensive solution for content delivery as well a means to manage and report on student learning outcomes. It provides a high-quality learning environment, with a quality rubric and assessment system capable of traditional and outcomes 
based grading. Rubrics can be generated by course personnel and archived in the repository for other educators to use.

Outcomes can be created at any level of an institution and multiple outcomes or accreditation schemes, and be linked to any assessment. Assessment can be done in-line in a very expedient manner, viewing the student submission and grading via a pop-up window. Feedback can only be provided to the student at each individual outcome in a rubric as well as overall feedback on the submission. It should be noted however, that a free iPad grader application for D2L allows for graders to mark up submissions and grade submissions.

The main weakness of D2L is the relative infancy of its outcomes reporting and analytics module. The analytics module currently doesn't offer freely customizable or graphical representations of reporting and has some limitations regarding drill-down capability and longitudinal reporting. The analytics module can provide tabular reporting on learning outcomes at multiple institutional levels, and both course personnel and administrators can run reports.

\subsection{LiveText}

LiveText (https://www.livetext.com/) is a continuous program improvement solution that focuses on strategic planning, outcomes assessment and reporting and institutional effectiveness. LiveText is primarily a standalone CPI tool that offers integration with LMS systems (Blackboard, Moodle, D2L) through API and LTI. This link allows for key pieces of submitted student evidence for outcomes based assessment, and provide rich feedback to students.

The key strengths of LiveText are the learning outcomes, assessment and analytics. LiveText allows for the creation of learning outcomes at any level in an institution, and assessment of outcomes in multiple instances. Outcomes can also be stored in a searchable repository for other educators to search and use. Assessment in LiveText is accomplished through customizable rubrics linked to outcomes, which can be done within the system while viewing the student submission. Rich feedback can be provided to the student, directly marking up and commenting on the submission. Outcomes analysis can be accomplished through by a series of table-based reports that can be run at any level with drill-down capability to the individual student level. LiveText offers on-demand reporting of student learning outcomes, with the capability for longitudinal reporting and data management.
The weaknesses of LiveText are the lack of graphical and customizable outcomes reporting and the lack of traditional grading. The two-stage nature of the system may also be undesirable for those seeking a singular solution, and will be required to administer non-outcomes related assessments.

\section{EVALUATION RESULTS}

Each software tool was classified and evaluated for each criterion and the results tabulated into the table shown in Fig. 1.

\section{CONCLUSIONS}

It is important to note that the evaluations presented in this paper are not meant to rank the software tools or promote the use of a single tool, but to inform the reader on the strengths and weaknesses of software tools. Each of the evaluated solutions is capable of being a part of, or a centerpiece of a data informed, outcomes based CPI process.

Ultimately, institutions must carefully consider a variety of factors when replacing an existing tool, or integrating a new software solution into an existing process, as this is fundamentally a change management issue[8]. Such factors include, but are not limited to[4], [5], [9]:

1. Stakeholder needs and requirements

2. Direction and leadership of CPI processes

3. Existing climate regarding new technology

4. Complexity and sustainability of tools

This paper is the initial evaluation of a small sample of software tools. Future work consists of continued analysis of LMS, CMS, CPI and other tools supporting data-informed, outcomes based, continuous program improvement.

\section{Acknowledgements}

The authors would like to acknowledge support from the DuPont Canada Chair in Engineering Education Research and Development. Support for the EGAD initiative was provided by Engineers Canada and the National Council of Deans of Engineering and Applied Science. 


\begin{tabular}{|c|c|c|c|c|c|c|c|}
\hline & & eLumen & Canvas & Moodle & $\begin{array}{l}\text { Waypoint } \\
\text { Outcomes }\end{array}$ & Desire2Learn & LiveText \\
\hline \multicolumn{2}{|c|}{ 1. LMS, L/CMS or CPI } & $\mathrm{CPI}$ & LMS & L/CMS & $\mathrm{CPI}$ & L/CMS \& CPI & $\mathrm{CPI}$ \\
\hline \multicolumn{2}{|c|}{ 2. Integration } & Custom & LTI \& API & LTI \& API & LTI \& API & LTI \& API & LTI \& API \\
\hline \multicolumn{8}{|c|}{ 3. Rubric-based assessment } \\
\hline \multirow{3}{*}{$\begin{array}{l}3 \mathrm{a} . \\
3 \mathrm{~b} . \\
3 \mathrm{c}\end{array}$} & \multirow{3}{*}{$\begin{array}{l}\text { Rubric Generation } \\
\text { Customizable } \\
\text { Rubric Repository }\end{array}$} & $\hat{\underline{\imath} \hat{\imath}}$ & 实记光 & $\hat{L}$ & 完记主 & 金全 & 全全 \\
\hline & & 定说 & 考记岂 & $\hat{\sim}$ & 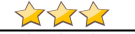 & $\hat{z} \tilde{Z}$ & $\hat{\omega} \tilde{Z}$ \\
\hline & & 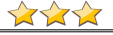 & 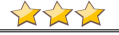 & $\hat{U}$ & 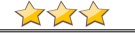 & $\hat{\sim} \hat{\sim}$ & 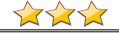 \\
\hline \multicolumn{8}{|c|}{ 4. Learning Outcomes } \\
\hline \multirow{4}{*}{$\begin{array}{l}4 \mathrm{ad} \\
4 \mathrm{~b} . \\
4 \mathrm{c} . \\
4 \mathrm{~d} .\end{array}$} & \multirow{4}{*}{$\begin{array}{l}\text { Multi-level capability } \\
\text { Multi-level mapping } \\
\text { Multi-instance mapping } \\
\text { Outcomes Repository } \\
\end{array}$} & 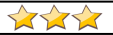 & $\hat{\Sigma} \hat{\imath}$ & $\hat{n}$ & $\hat{\imath} \hat{\imath}$ & 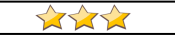 & 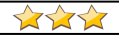 \\
\hline & & 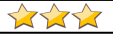 & $\hat{\Sigma}$ & $\hat{\Sigma}$ & $\hat{\vec{n} \hat{\imath}}$ & $\hat{\omega} \hat{厶}$ & $\hat{\bar{L}} \hat{厶}$ \\
\hline & & 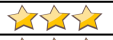 & 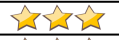 & $\hat{\tilde{L} \hat{\imath}}$ & $\hat{\omega} \hat{厶} \hat{n}$ & 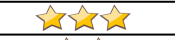 & $\hat{\underline{1}} \hat{n} \hat{n}$ \\
\hline & & 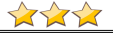 & 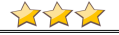 & 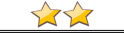 & 元光 & $\hat{\omega} \hat{n}$ & 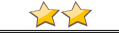 \\
\hline \multicolumn{8}{|c|}{ 5. Assessment } \\
\hline \multirow{4}{*}{$\begin{array}{l}5 \mathrm{a} . \\
5 \mathrm{~b} . \\
5 \mathrm{c} . \\
5 \mathrm{~d} .\end{array}$} & \multirow{4}{*}{$\begin{array}{l}\text { Direct \& Indirect Evidence } \\
\text { Multiple assessors } \\
\text { In-line grading } \\
\text { In-line feedback }\end{array}$} & 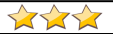 & 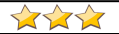 & $\hat{\imath} \hat{\imath}$ & 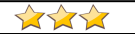 & 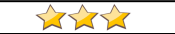 & $\hat{\imath} \hat{\imath}$ \\
\hline & & 金负 & 全全 & 西负 & 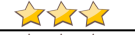 & 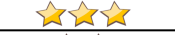 & 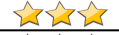 \\
\hline & & $\hat{\imath}$ & 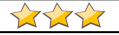 & $\hat{U}$ & 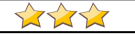 & $\hat{\omega} \hat{\imath}$ & 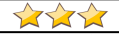 \\
\hline & & $\hat{厶}$ & 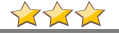 & $\hat{\imath}$ & 狊己解 & $\hat{z} \tilde{L}$ & 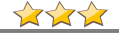 \\
\hline
\end{tabular}

6. Analytics

\begin{tabular}{|c|c|c|c|c|c|c|c|}
\hline 6a. & Multi-level reporting & 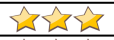 & $\hat{\omega} \tilde{\omega}$ & $\tilde{a}$ & 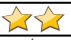 & 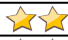 & 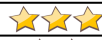 \\
\hline 6b. & Tabular reporting & 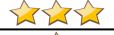 & $\hat{\imath}$ & $\hat{\sim}$ & $\hat{\sim}$ & $\hat{\underline{1}} \hat{L}$ & $\hat{\omega} \tilde{\omega}$ \\
\hline 6c. & Graphical reporting & $\hat{Z}$ & $\hat{\Omega}$ & $\hat{\Sigma}$ & $\hat{\Sigma}$ & $\hat{\omega}$ & $\hat{\vec{n}}$ \\
\hline 6d. & On-demand reporting & 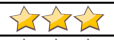 & $\hat{\imath} \hat{\imath}$ & $\hat{n}$ & $\hat{\Delta} \hat{\imath}$ & $\hat{\bar{n} \hat{U}}$ & 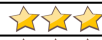 \\
\hline $6 e$. & Longitudinal reporting & $\hat{\omega} \hat{\alpha} \hat{n}$ & $\hat{\omega}$ & $\hat{W}$ & $\hat{\tilde{\omega} \hat{U}}$ & $\hat{\tilde{L} \hat{W}}$ & 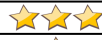 \\
\hline $6 f$. & Custom group reporting & 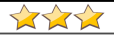 & $\hat{\Sigma}$ & $\hat{\Sigma}$ & $\hat{\imath}$ & $\hat{\imath}$ & $\hat{Z}$ \\
\hline
\end{tabular}

\section{Pricing}

\begin{tabular}{l|l|c|c|c|c|c|c|}
\hline \multicolumn{1}{l}{ 7. Pricing } & \multicolumn{1}{c|}{ Self or SaaS } & SaaS & Self & SaaS & Self or SaaS & SaaS \\
\cline { 2 - 7 } 7a. & Hosting Model & Yearly License & Open-source & Open-source & Yearly License & Yearly License & Yearly License \\
\cline { 2 - 7 } 7b. & Subscription & FTE Scaled & FTE Scaled $(\$ 28)$ & Free & FTE Scaled $(\$ 12-20)$ & FTE Scaled & $\$ 80-98^{\circ}$ \\
\hline
\end{tabular}

*The cost of LiveText is determined by either Institutional purchase ( $\$ 80$ per FTE) or Student purchase ( $\$ 98$ per student).

Fig. 1. Evaluation of selected software tools 


\section{References}

[1] J. Allan, "Learning outcomes in higher education," Studies in Higher Education, vol. 21, no. 1, pp. 93-108, 1996. Available at: http://dx.doi.org/10.1080/03075079612331381487

[2] J. Biggs, "What the Student Does: teaching for enhanced learning," Higher Educ. Res. \& Development, vol. 18, no. 1, pp. 57-75, Apr. 1999. Available at: http://dx.doi.org/10.1080/0729436990180105

[3] T. W. Banta, Hallmarks of Effective Outcomes Assessment: Assessment Update Collections, 1 st ed. Wiley, 2004.

[4] C. Blaich and K. Wise, "From Gathering to Using Assessment Results," (NILOA Occasional Paper No.8). Urbana, IL: University of Illinois and Indiana University, National Institute for Learning Outcomes Assessment (NILOA) 2011. Available at: http://www.learningoutcomeassessment.org/documents /Wabash_001.pdf

[5] G. R. Baker, N. A. Jankowski, S. Provezis, and J. Kinzie, "Using Assessment Results: Promising Practices of Institutions That Do It Well," Urbana, IL: University of Illinois and Indiana University, National Institute for Learning Outcomes Assessment (NILOA) 2012. Available at:

http://www.learningoutcomeassessment.org/UsingAsse ssmentResults.htm
[6] T. W. Banta and C. Blaich, "Closing the Assessment Loop," Change: The Magazine of Higher Learning, vol. 43, no. 1, pp. 22-27, Dec. 2010. Available at: http://dx.doi.org/10.1080/00091383.2011.538642

[7] E. Heinrich, J. Milne, A. Ramsay, and D. Morrison, "Recommendations for the use of e-tools for improvements around assignment marking quality," Assessment \& Evaluation in Higher Education, vol. 34, no. 4, pp. 469-479, Aug. 2009. Available at: http://dx.doi.org/10.1080/02602930802071122

[8] G. Scott, "Effective change management in higher education," Educause review, vol. 38, pp. 64-78, 2003. Available at:

http://www.educause.edu/ir/library/pdf/ERM0363.pdf

[9] A. L. McCann, "Factors affecting the adoption of an eassessment system," Assessment \& Evaluation in Higher Education, vol. 35, no. 7, pp. 799-818, Dec. 2010. Available at: http://dx.doi.org/10.1080/02602930902981139 